\title{
PENGARUH PENERAPAN TEKNOLOGI INFORMASI PADA USAHA MIKRO KECIL DAN MENENGAH DI KOTA SURAKARTA
}

\author{
Khabib Alia Akhmad $\circledast^{1)}$ dan Singgih Purnomo $\varpi^{2)}$ \\ ${ }^{1}$ Manajemen, Fakultas Hukum dan Bisnis, Universitas Duta Bangsa Surakarta \\ ${ }^{2}$ Agribisns,Fakultas Sains dan Teknologi, Universitas Duta Bangsa Surakarta \\ ${ }^{1,2}$ Jl. Pinang Raya No. 47 Cemani, Kab. Sukoharjo, 57552 \\ E-mail : khabib_alia@udb.ac.id ${ }^{1)}$, singgih_purnomo@udb.ac.id ${ }^{2)}$
}

\begin{abstract}
ABSTRAK
Keberadaan Usaha Mikro Kecil dan Menengah (UMKM) merupakan salah satu pihak yang cukup berperan bagi pembangunan suatu negara. Di negara-negara berkembang keberadaan UMKM memberikan pengaruh kepada perekonomian negaranya, dan di Indonesia eksistensi UMKM secara langsung memberikan kontribusi bagi Pendapatan Domestik Bruto (PDB) Negara. Eksistensi UMKM menghadapi berbagai tantangan, salah satunya adalah keberadaan teknologi. Adanya perkembangan teknologi yang semakin maju menuntut para pelaku UMKM untuk dapat menggunakan dan memanfaatkan perkembangan teknologi tersebut, salah satu diantaranya adalah penggunaan Teknologi Informasi (TI) bagi pengembangan usaha para pelaku UMKM. Tujuan dari penelitian ini adalah untuk mengetahui pengaruh dari penggunaan teknologi informasi berupa e-commerce pada pelaku UMKM di Kota Surakarta serta kendala-kendala yang dihadapi UMKM di Kota Surakarta dalam menerapkan teknologi informasi tersebut untuk menunjang kegiatan usahanya. Metode penelitian yang digunakan dalam penelitian ini adalah deskriptif kualitatif, dengan teknik pengumpulan data melalui indept interview, observasi, wawancara terstruktur dan FGD. Hasil penelitian menunjukkan bahwa teknologi informasi memberikan dampak bagi pelaku UMKM di Kota Surakarta berupa peningkatan jumlah pesanan yang diterima, adanya peningkatan jumlah produksi, peningkatan pendapatan dan penambahan jumlah konsumen yang baru. Untuk kendala utama yang dihadapi oleh pelaku UMKM di Kota Surakarta dalam pemanfaatan teknologi informasi adalah berasal dari faktor internal pelaku UMKM yakni belum adanya pemisahan manajemen kegiatan produksi maupun pemasaran, serta kemampuan penguasaan teknologi yang terbatas.
\end{abstract}

Kata Kunci: UMKM, Pengembangan Usaha, Teknologi Informasi, Penggunaan TI, Dampak TI

\section{PENDAHULUAN}

Keberadaan pelaku usaha mikro kecil menengah (UMKM) di negara-negara berkembang merupakan hal yang penting karena keberadaannya memberikan kontribusi bagi perkembangan negara-negara tersebut, khususnya bagi pertumbuhan ekonomi, penciptaan lapangan kerja dan pengentasan kemiskinan (Afolayan, dkk., 2015, Tarute and Gatautis, 2014), yang mana halhal di atas merupakan masalah-masalah klasik yang kerap kali terjadi di negara berkembang dan membutuhkan solusi. Begitu pula yang dihadapi oleh negara Indonesia, terjadinya krisis moneter di tahun 1997 dan 1998 yang melanda negara-negara di Asia termasuk di Indonesia, menjadikan sebuah momentum bagi pemerintah untuk menaruh perhatian kembali akan eksistensi UMKM yang pada saat terjadinya krisis tersebut, yang mana adanya krisis tersebut bagi pelaku UMKM cenderung tidak berdampak bila dibandingkan dengan usaha-usaha besar yang mengalami kebangkrutan.

Di Indonesia keberadaan UMKM telah terbukti memberikan dampak pada perekonomian nasional, adapun peran UMKM terhadap perekonomian nasional dapat diklasifikasikan menjadi tiga yakni: jumlah industrinya yang besar dan terdapat dalam setiap sektor ekonomi, potensinya yang besar dalam penyerapan tenaga kerja, dan berkontribusi pada pembentukan PDB. Di Indonesia keberadaan UMKM memberikan sumbangan lebih dari $95 \%$ bagi bisnis yang ada (Rahayu and Day, 2015).

Pengertian usaha mikro, kecil dan menengah (UMKM) di Indonesia telah dijelaskan secara lengkap di dalam Undang-Undang Republik Indonesia No. 20 Tahun 2008 tentang UMKM. Di mana pengertian dari usaha mikro, kecil dan menengah yakni usaha mikro adalah usaha produktif milik orang perorangan dan/atau badan usaha perorangan yang memiliki kriteria usaha mikro sebagaimana diatur dalam undang-undang tersebut. Untuk pengertian usaha kecil yakni usaha ekonomi produktif yang berdiri sendiri, yang dilakukan oleh orang perorangan atau badan usaha yang buka merupakan anak perusahan atau bukan anak cabang yang dimiliki, dikuasai atau menjadi bagian, baik langsung maupun tidak langsung, dari usaha menengah atau usaha besar yang memenuhi kriteria usaha kecil sebagaimana dimaksud dalam undang-undang tersebut. Sedangkan pengertian usaha menengah menurut undang-undang tersebut adalah usaha ekonomi produktif yang berdiri 
sendiri, yang dilakukan oleh orang perorangan atau badan usaha yang bukan merupakan anak perusahaan atau cabang perusahaan dengan Usaha Kecil atau Usaha Besar dengan jumlah kekayaan bersih atau hasil penjualan tahunan sebagaimana diatur dalam undangundang ini. Untuk kriteria yang digunakan mendefinisikan UMKM didasarkan atas nilai kekayaan bersih atau nilai aset tidak termasuk tanah dan bangunan tempat usaha, atau hasil penjualan tahunan yang dimilikinya.

Adanya perkembangan UMKM dipengaruh oleh berbagai faktor diantaranya adalah faktor ekonomi makro, faktor politik-institusional, faktor sosial budaya dan faktor peluang pasar. Perkembangan teknologi informasi yang semakin pesat turut serta memberikan pengaruh kepada UMKM, sehingga membuat para pelaku UMKM mencoba berbagai teknologi informasi yang ada. Dengan adanya pemanfaatan teknologi diharapkan dapat memainkan peran yang vital di dalam proses bisnis UMKM tersebut.

Kehadiran Teknologi Informasi (TI) mengubah caracara di dalam suatu bisnis dari yang semula konvensional menjadi sesuatu yang baru baik dari sisi peluang maupun tantangannya. Sebagai salah satu pilar bagi peradaban manusia, keberadaan teknologi informasi harus dapat memberikan nilai tambah bagi individu maupun masyarakat luas. Salah satu contohnya adalah teknologi informasi yang digunakan sebagai media pendidikan dilakukan dengan menggunakan media-media komunikasi.

Teknologi informasi adalah suatu teknologi yang digunakan untuk mengolah data dalam berbagai cara untuk menghasilkan informasi yang berkualitas yang digunakan oleh berbagai pihak dan merupakan informasi yang strategis untuk pengambilan keputusan, menurut Sutabri (2016). Sedangkan menurut Mulyadi (2014), teknologi informasi adalah mencakup komputer baik perangkat keras dan perangkat lunak serta berbagai peralatan kantor elektronik, perlengkapan pabrik dan telekomunikasi.

Dari beberapa definisi diatas dapat disimpulkan bahwa teknologi informasi adalah suatu gabungan dari teknologi komputasi dan komunikasi baik dalam bentuk software maupun hardware yang digunakan oleh pihakpihak yang berkepentingan untuk mengolah data guna menghasilkan informasi yang relevan untuk pengambilan keputusan yang strategis.

Bagi pelaku UMKM, teknologi informasi berguna karena kegiatan usahanya tidak saja hanya berhadapan dengan UMKM sejenis akan tetapi juga menghadapi serbuan produk-produk dari luar yang memiliki kualitas produk yang dapat lebih baik. Penelitian Lubis (2016) yang menganalisis pemanfaatan teknologi informasi pada usaha mikro kecil dan menengah di Kota Jambi, menunjukkan hasil rendahnya pemahaman terhadap manfaat teknologi informasi; rendahnya ketersediaan investasi; dan rendahnya dukungan lembaga pemerintah.
Peningkatan pengadopsian teknologi informasi pada usaha mikro kecil dan menengah di negara-negara maju cukup signifikan (Niebel, 2018; Rahayu and Day, 2015), akan tetapi berbeda dengan negara-negara berkembang yang mana tingkat penggunaan teknologi informasi relatif rendah (Yunis dkk., 2017; Rahayu and Day, 2015). Dalam berbagai penelitian yang dilakukan, manfaat yang didapatkan oleh UMKM yang mengadopsi teknologi informasi, diantaranya adanya peningkatan pemasaran (Singh, 2011), peningkatan komunikasi yang efisien dan efektif (Apulu dkk., 2011; Singh, 2011; Pickernell dkk., 2013; Ajayi dan Olayungbo, 2014), serta penggunaan teknologi informasi telah membantu organisasi mencapai pertumbuhan yang lebih efisien, efektif, inovatif dan kompetitif secara global (Rahayu and Day, 2015; Tarute dan Gatautis, 2014)

Terdapat dua faktor yang mempengaruhi pelaku UMKM mengadopsi teknologi informasi, seperti yang disampaikan Ghobakhloo dkk. (2011) faktor tersebut adalah faktor internal dan eksternal. Faktor internal terdiri atas keputusan dari pelaku UMKM untuk mengadopsi teknologi informasi, adanya modal atau anggaran untuk pengembangan teknologi informasi, sumber daya manusia bidang TIK yang ada di UMKM, serta adanya aplikasi teknologi informasi yang sesuai dengan kebutuhan dan budaya/karakteristik UMKM itu sendiri. Di sisi lain faktor eksternal yang mempengaruhi adopsi teknologi informasi oleh UMKM diantaranya lingkungan yang kompetitif (persaingan dengan UMKM lain), pemerintah, pelanggan dan supplier, serta konsultan teknologi informasi dan vendor.

Hambatan dalam pemanfaatan teknologi informasi pada UMKM jika diklasifikasikan menjadi dua yakni hambatan internal dan eksternal (Apulu dkk., 2011; Awa dkk., 2011). Adapun hambatan internal biasanya mencakup budaya organisasi, kurangnya sikap pemilik/manajer terhadap teknologi informasi, dan tingkat pelatihan bagi sumber sedangkan hambatan eksternal diantaranya kurangnya fasilitas infrastruktur dan modal yang terbatas.

Hasil dari penelitian yang telah dilakukan oleh para peneliti didapatkan kendala-kendala yang dihadapi oleh pelaku UMKM dalam mengadopsi e-commerce diantaranya kendala koneksi dan jaringan (As'ad dkk. , 2012), adanya faktor pendorong, manusia dan sumber informasi (Govindaraju \& Chandra, 2012), sedangkan menurut Maryeni, dkk. (2014) adopsi e-commerce oleh UMKM dipengaruhi 4 faktor yakni tingkat kompleksitas e-commerce dipandang terlalu rumit untuk didiimplementasikan oleh UMKM, perencanaan IT dalam tahap awal, user TI Skill dan management Suport. Penelitian yang dilakukan oleh Payu (2013) kendala utama pemanfaatan teknologi informasi pada pelaku UMKM di wilayah Kota Gorontalo adalah karena keterbatasan kemampuan sumber daya manusia.

Berbeda dengan penelitian yang dilakukan oleh (Rahayu and Day, 2015) menemukan hasil bahwa manfaat yang dirasakan, kesiapan teknologi, inovasi 
pemilik, kemampuan Informasi dan Teknologi (IT) pemilik dan pengalaman IT pemilik adalah faktor penentu yang mempengaruhi UKM Indonesia dalam mengadopsi e-commerce.

Perbedaan penelitian ini dengan penelitian sebelumnya adalah lebih fokus pada dampak dan kendala pemanfaatan teknologi informasi, khususnya pemanfaatan e-commerce di dalam kegiatan penjualan dan pemasaran produk UMKM, karena penelitianpenelitian sebelumnya hanya fokus pada satu tujuan penelitian saja. Adapun rumusan masalah penelitian ini adalah apakah dampak dari pemanfaatan teknologi informasi bagi pelaku UMKM di Kota Surakarta dan kendala-kendala yang dihadapinya di dalam penggunaan teknologi informasi. Sedangkan tujuan penelitian adalah untuk mengetahui seberapa besar pemanfaatan teknologi informasi di kalangan pelaku UMKM di Kota Surakarta untuk menunjang kegiatan usahanya dan kendalakendala yang dihadapi di dalam pemanfaatan teknologi informasi tersebut.

\section{RUANG LINGKUP}

Pemahaman akan kebutuhan UMKM menjadi suatu yang sangat penting bagi stakeholder yang membidangi UMKM karena peran UMKM yang cukup signifikan terhadap perekonomian suatu bangsa. Oleh karenanya dengan memberikan dukungan bagi kemajuan UMKM menjadi sesuatu hal yang harus dilakukan. Salah satunya adalah dukungan akan kebutuhan teknologi yang dapat digunakan oleh pelaku UMKM dalam meningkatkan pendapatannya. Cakupan permasalahan dalam penelitian ini lebih fokus pada manfaat yang didapatkan oleh pelaku UMKM di dalam penggunaan teknologi informasi yang menunjang kegiatan usaha serta mengetahui kendala-kendala yang dihadapi di dalam penggunaan teknologi informasi tersebut.

Dalam penelitian ini hanya membatasi pada pelaku UMKM yang memanfaatkan teknologi informasi dalam bentuk pemanfaatan electronic commerce (e-commerce) dalam pemasaran produk yang diproduksinya pada pelaku UMKM di Kota Surakarta. Hasil yang didapatkan dapat menjadi bahan pertimbangan bagi para stakeholder yang membidangi UMKM untuk meningkatkan dan mengembangkan usaha para pelaku UMKM.

\section{BAHAN DAN METODE}

Dalam penelitian ini menggunakan pendekatan secara kualitatif, yakni suatu cara yang digunakan untuk memahami sifat-sifat dari suatu fenomena objek yang diteliti, sehingga dapat diketahui dan di analisis pokok permasalahannya yang muncul dan di ambil alternatif pemecahannya. Desain penelitian yang digunakan dalam penelitian ini adalah penelitian deskriptif kualitatif. Pemakaian pendekatan ini memiliki tujuan untuk dapat mendeskripsikan mengenai perilaku, peristiwa maupun kegiatan tertentu secara terperinci serta mendalam. Di mana teknik pengumpulan datanya melalui in-depth interview, observasi, wawancara terstruktur dan FGD terhadap pelaku UMKM di Kota Surakarta terkait penelitian yang dilakukan serta data sekunder yang berasal dari Dinas Koperasi dan UKM di Kota Surakarta mengenai jumlah pelaku UMKM. Untuk teknik analisis dengan menggunakan kajian Fenomenologis bertujuan mengklarifikasi situasi yang dialami oleh para pelaku UMKM berkaitan dengan dampak dari pemanfaatan teknologi informasi serta kendala-kendala yang dihadapinya di dalam penggunaan teknologi informasi tersebut.

Untuk informan pada penelitian ini adalah pelaku UMKM yang aktif d Kota Surakarta sudah menggunakan teknologi informasi baik berupa media sosial, platform chatting, website pribadi dan marketplace. Untuk distribusi informan didasarkan pada pertimbangan jenis usaha yang terbanyak di Kota Surakarta. Dari jenis usaha UMKM tersebut ditetapkan jumlah informan secara proporsional terhadap jenis usahanya, sehingga jumlah informan dalam survei ditetapkan sebanyak 120 pelaku UMKM.

\section{PEMBAHASAN}

Untuk dapat bersaing di dalam perkembangan perekonomian yang semakin ketat, pelaku UMKM harus dapat meningkatkan skill di berbagai bidang. Salah satu cara yang dapat dilakukan oleh UMKM agar mampu bersaing dalam era saat ini adalah dengan memanfaatkan teknologi informasi yang tersedia. Selain untuk meningkatkan kemampuan bersaing dengan para pelaku usaha besar, keberadaan teknologi informasi dapat pula untuk membantu pelaku UMKM beroperasi di dalam skala internasional. Di sisi lain dengan keberadaan teknologi informasi bagi UMKM dapat menjadikannya sebagai sarana promosi yang efektif.

Untuk data kegiatan usaha yang dilakukan oleh pelaku UMKM tampak pada tabel 1 di bawah ini yang terkonsentrasi pada sektor kuliner sebanyak 50 UMKM atau $42 \%$, sektor fashion sebanyak 34 UMKM atau 18\%, sektor kerajinan sebanyak 26 UMKM atau 22\%, sektor perdagangan sebanyak 6 UMKM atau 5\% dan sektor jasa sebanyak 4 UMKM atau $3 \%$.

Tabel 1. Profil UMKM Berdasarkan Jenis Usaha

\begin{tabular}{|l|l|l|}
\hline Jenis Usaha & Jumlah UMKM & Persentase \\
\hline Kuliner & 50 & $42 \%$ \\
\hline Fashion & 34 & $28 \%$ \\
\hline Kerajinan & 26 & $22 \%$ \\
\hline Perdagangan & 6 & $5 \%$ \\
\hline Jasa & 4 & $3 \%$ \\
\hline Jumlah & 120 & $100 \%$ \\
\hline
\end{tabular}

Salah satu bagian dari pemanfaatan teknologi informasi dalam bidang bisnis dan perdagangan adalah electronic commerce (e-commerce). E-commerce adalah suatu jenis dari mekanisme bisnis secara elektronik yang memfokuskan diri pada transaksi bisnis berbasis individu dengan menggunakan internet (teknologi berbasis jaringan digital) sebagai medium pertukaran barang atau 
jasa baik antara dua buah institusi (business to business) dan konsumen langsung (business to consumer) (Karmawan et.al, 2010).

Media e-commerce yang digunakan oleh informan dapat diklasifikasikan berdasarkan jenisnya dibagi menjadi tiga yakni (1) Consumer-to-Consumer (C2C) Ecommerce yakni pelaku UMKM langsung memasarkan produknya ke konsumen baik lewat marketplace seperti Shoope,Tokopedia dan Bukalapak. Lewat social chatting seperti Whatsapp maupun website yang mempertemukan antara penjual dan pembeli seperti Facebook dan Instagram sebanyak 25 pelaku UMKM (2) Online-toOffline (O2O) E-commerce dalam hal ini pelaku UMKM menggunakan dua saluran baik online maupun offline untuk pemasaran produknya seperti Go-jek dan Grab sebanyak 30 pelaku UMKM dan (3) menggunakan kedua jenis media e-commerce sebanyak 65 UMKM, tampak pada grafik 1 .

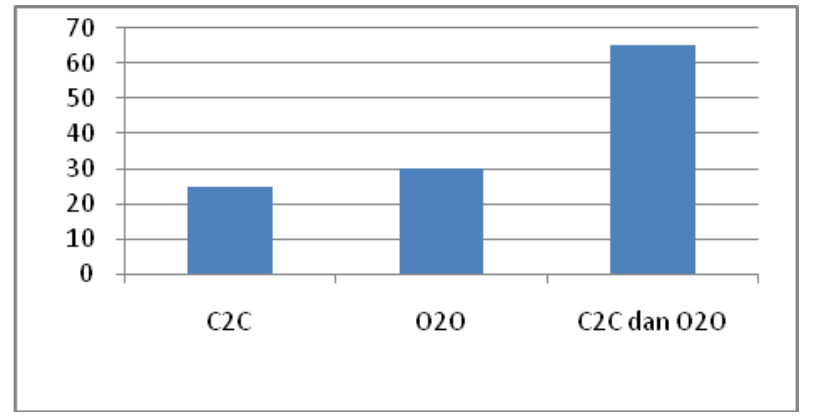

\section{Grafik 1. Jumlah UMKM Pengguna Media $E$ - Commerce Berdasarkan Jenisnya}

Dari hasil in-depth interview, observasi, wawancara terstruktur dan FGD kepada pelaku UMKM di Kota Surakarta diperoleh informasi terkait penggunaan $e$ commerce maka dapat dijabarkan mengenai dampak dan kendala yang dihadapi oleh pelaku UMKM terhadap penggunaan teknologi informasi sebagai berikut:

\subsection{Dampak Penggunaan TI}

Kegiatan penggunaan teknologi informasi yang dilakukan oleh UMKM di Kota Surakarta dalam hal ini adalah pemanfaatan e-commerce di dalam kegiatan penjualan dan pemasaran produk UMKM. Pemanfaatan fasilitas teknologi informasi tersebut untuk membantu dalam kegiatan usaha pelaku UMKM.

Berdasarkan dampak yang ditimbulkan dari penggunaan TI oleh pelaku UMKM terhadap kegiatan usahanya, dari hasil wawancara kepada para informan dapat diklasifikasikan sebagai berikut:

1. Dampak penggunaan TI terhadap adanya peningkatan jumlah pesanan

Pemanfaatan teknologi informasi yang dilakukan oleh pelaku UMKM dengan menggunakan berbagai platform e-commerce yang dimiliki dan dikuasai seperti melalui marketplace, social chatting ataupun gabungan keduanya ternyata memberikan tambahan jumlah pesanan dibandingkan pada saat sebelum menggunakan teknologi informasi tersebut. Hal ini dialami pada 94 dari 120 pelaku UMKM atau $78 \%$ informan yang menyatakan bahwa setelah menggunakan teknologi informasi terjadi peningkatan jumlah pesanan atas produk yang mereka produksi. Adapun dampak penggunaan TI terhadap adanya peningkatan jumlah pesanan dapat di lihat pada grafik 2 .

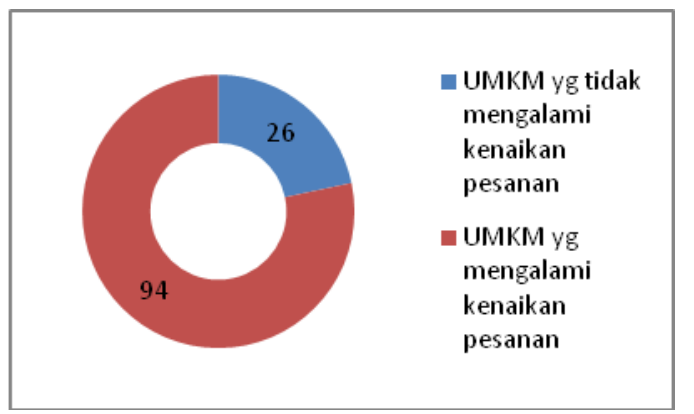

Grafik 2. Dampak TI Terhadap Jumlah Pesanan

Adapun besaran rata-rata peningkatan jumlah pesanan sebelum dengan sesudah menggunakan teknologi informasi menurut hasil wawancara yang terjadi pada pelaku UMKM, rata-rata mengalami kenaikan jumlah pesanan sebesar $15 \%$.

2. Dampak penggunaan TI terhadap adanya peningkatan Jumlah produksi

Produksi adalah suatu kegiatan perusahaan yang menghasilkan sesuatu baik berbentuk barang maupun jasa dalam suatu periode waktu, yang selanjutnya dihitung sebagai nilai tambah perusahaan (Fahmi, 2016). Peningkatan jumlah produksi berkaitan dengan jumlah produk yang dihasilkan dalam hal ini berupa barang. Hasil penggunaan teknologi informasi, dampaknya terhadap produksi dapat dinyatakan bahwa terdapat 80 pelaku UMKM atau sebanyak $67 \%$ informan yang menyatakan mengalami peningkatan jumlah produksi, hal tersebut dipicu salah satunya dengan adanya peningkatan jumlah pesanan yang terjadi. Adapun dampak penggunaan TI terhadap adanya peningkatan jumlah produksi tampak pada grafik 3 .

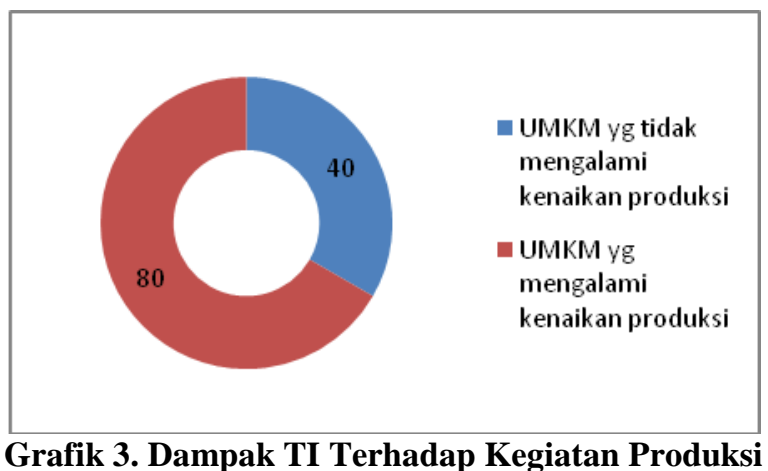

Grafik 3. Dampak TI Terhadap Kegiatan Produksi 
3. Dampak penggunaan TI terhadap adanya peningkatan pendapatan

Pendapatan merupakan jumlah yang dibebankan kepada langganan atas barang dan jasa yang dijual. Pendapatan pada dasarnya adalah semua penerimaan, baik tunai maupun bukan tunai yang merupakan hasil dari penjualan barang atau jasa. Peningkatan pendapatan biasanya dipicu oleh peningkatan pemasaran dan penjualan produk oleh pelaku UMKM. Hanya saja dari hasil penelitian ini pelaku UMKM yang mengalami peningkatan pendapatan sebanyak 75 UMKM atau 63\% yang berasal dari penjualan produknya dengan memanfaatkan teknologi informasi yang dikuasainya, tampak pada grafik 4.

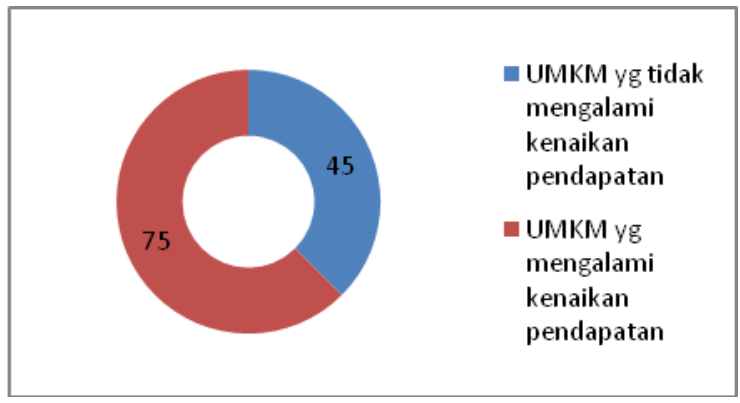

Grafik 4. Dampak TI Terhadap Pendapatan

4. Dampak penggunaan TI terhadap adanya penambahan jumlah konsumen baru

Dampak lain dari penggunaan teknologi informasi yang terjadi pada pelaku UMKM adalah terjadinya penambahan konsumen baru. Baik konsumen baru maupun konsumen yang telah melakukan transaksi sebelumnya. Penambahan ini merupakan hal yang sangat baik bagi pelaku UMKM karena dengan adanya penambahan konsumen, diharapkan akan dapat meningkatkan tambahan pendapatan. Hal ini terjadi pada 74 UMKM pelaku UMKM atau sebanyak $62 \%$ informan yang mengalaminya, hal ini terlihat pada grafik 5 .

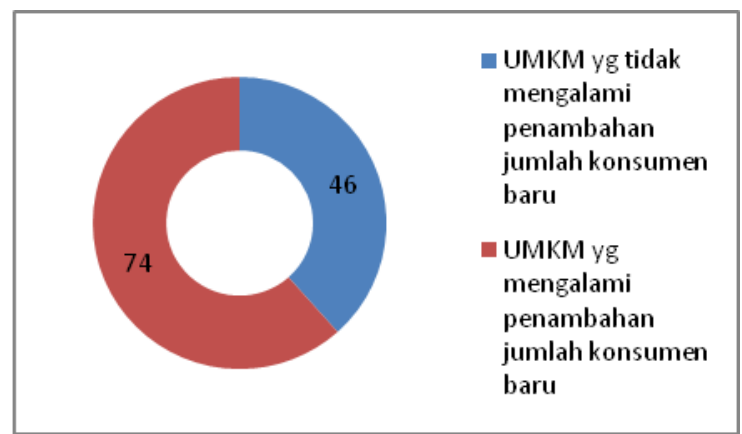

Grafik 5. Dampak TI Terhadap Penambahan Konsumen

Sehingga jika diklasifikasikan dampak yang ditimbulkan dari penggunaan teknologi informasi bagi para pelaku UMKM dapat dibagi menjadi empat hal dan jika diurutkan berdasarkan jumlah UMKM yang mengalami dampak dari penggunaan TI tersebut maka pada variabel peningkatan jumlah pesanan terdapat 94 pelaku UMKM atau sekitar 78\% yang mengalaminya, variabel peningkatan jumlah produksi sebanyak 80 pelaku UMKM atau sekitar $67 \%$, variabel peningkatan jumlah pendapat terjadi pada 75 pelaku UMKM atau sekitar $63 \%$ dan adanya penambahan konsumen baru dialami oleh 74 pelaku UMKM atau sekitar $62 \%$, seperti terlihat pada tabel 2 .

Tabel 2. Dampak Penggunaan TI

\begin{tabular}{|l|l|c|c|}
\hline No & \multicolumn{1}{|c|}{ Variabel jumlah } & Total UMKM & Persentase \\
\hline 1. & $\begin{array}{l}\text { Peningkatan jun } \\
\text { pesanan }\end{array}$ & $78 \%$ \\
\hline 2. & $\begin{array}{l}\text { Peningkatan jumlah } \\
\text { produksi }\end{array}$ & 80 & $67 \%$ \\
\hline 3. & $\begin{array}{l}\text { Peningkatan jumlah } \\
\text { pendapatan }\end{array}$ & 75 & $63 \%$ \\
\hline 4. & $\begin{array}{l}\text { Penambahan } \\
\text { konsumen baru }\end{array}$ & 74 & $62 \%$ \\
\hline
\end{tabular}

Dari hasil wawancara penelitian pula kepada para pelaku UMKM dan hasil FGD adanya peningkatan jumlah pesanan, peningkatan jumlah produksi, peningkatan pendapatan dan penambahan konsumen baru disebabkan para pelaku UMKM sudah menggunakan media online dengan memanfaatkan berbagai platform semisal Marketplace, di dalam platform tersebut, pelaku UMKM dapat mengunggah berbagai produk untuk ditawarkan kepada konsumen di Tokopedia, Bukalapak, dan Shopee. Serta secara Classifed yakni menggunakan website yang telah tersedia yang hanya berfungsi untuk mempertemukan antara penjual dan pembeli namun tidak memfasilitasi transaksi jual beli online, seperti di Instagram dan Facebook, serta platform social chatting seperti Whatsapp.

Terjadinya dampak dari penggunaan teknologi informasi tersebut ternyata tidak semua pelaku UMKM mengalami keempat-empatnya yakni kenaikan pesanan, kenaikan produksi, kenaikan pendapatan dan penambahan jumlah konsumen baru secara bersamaan. Jika dihitung berdasarkan hasil wawancara kepada para informan, pelaku UMKM yang mengalami keempat dampak tadi ternyata hanya terjadi pada 28 pelaku UMKM, sedangkan sisanya bervariasi yakni 42 pelaku UMKM mengalami tiga dampak, 38 pelaku UMKM mengalami dua dampak dan 12 UMKM hanya mengalami satu dampak dari penggunaan teknologi informasi tersebut, terlihat pada grafik 6 . 


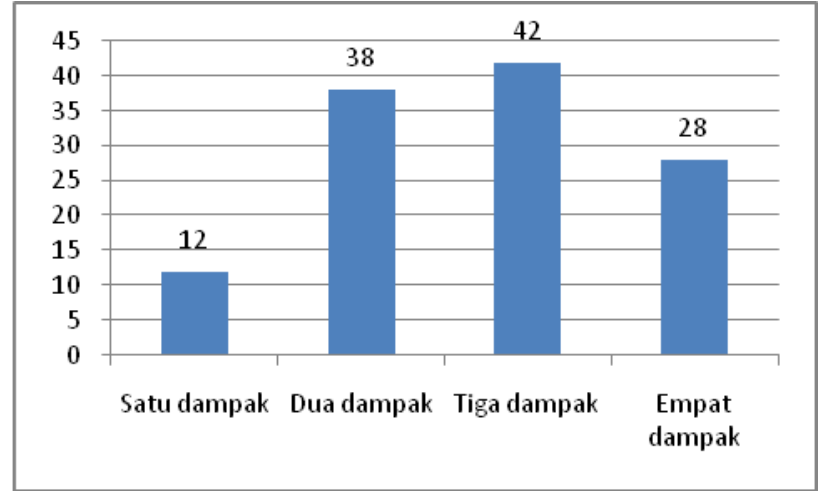

\section{Grafik 6. Jumlah UMKM Yang Terdampak Penggunaan TI}

\subsection{Kendala Penggunaan TI}

Dengan memanfaatkan teknologi informasi pada kegiatan usahanya, bagi para pelaku UMKM hal tersebut merupakan bentuk adaptasi atas perkembangan teknologi yang berkembang. Kenyataan yang ada di lapangan, banyak pelaku UMKM di Kota Surakarta yang masih kesulitan di dalam mengadakan dan melaksanakan kegiatan usahanya melalui pemanfaatan teknologi informasi.

Berdasarkan hasil observasi dan wawancara, kendala utama yang dihadapi oleh pelaku UMKM dalam penggunaan teknologi informasi berasal dari internal pelaku UMKM sendiri yakni belum adanya pemisahan antara kegiatan produksi atas usahanya dengan kegiatan pemasaran, hal ini disebabkan pelaku UMKM kesulitan di dalam membagi waktu karena mereka harus melakukan berbagai kegiatan lainnya seperti pembelian bahan baku, produksi, pemasaran secara bersamaan atau dilakukan sendiri karena belum melibatkan orang lain yang ditugasi khusus untuk mengelolanya. Hal ini terjadi pada $86 \%$ informan atau sebanyak 103 pelaku UMKM yang di observasi dan wawancara, sedangkan sisanya sebanyak $14 \%$ atau 17 pelaku UMKM sudah mulai memisahkan kegiatan produksi dengan kegiatan pemasaran, hal ini dilakukan dengan melibatkan pihak lain khususnya keterlibatan keluarga, terutama anak-anak mereka yang sudah melek akan teknologi untuk membantu atau menggunakan jasa orang lain untuk turut membantu di dalam kegiatan pemasarannya melalui $e$ commerce.

Kendala selanjutnya adalah kemampuan penguasaan teknologi yang masih rendah. Sebagian besar pelaku UMKM yang ditemui menggunakan telepon pintar (smartphone) sebagai alat yang digunakan dalam pemasaran e-commerce-nya. Masih banyak pelaku UMKM yang masih memiliki keterbatasan di dalam pemanfaatan dan penggunaan teknologi tersebut, khususnya pemanfaatan gawai yang dimilikinya karena teknologi atau aplikasi yang ada digawai tersebut merupakan sesuatu hal yang baru bagi para pelaku UMKM. Adapun kesulitan yang dialami oleh pelaku UMKM tersebut diantaranya adalah belum mengetahui bagaimana cara untuk mengunduh aplikasi untuk berjualan, kalaupun sudah ter unduh, kesulitan berikutnya adalah bagaimana mengisi dan menyusun isi dari informasi produknya yang akan dibagi di marketplace dan media sosial yang dimilikinya, kendala selanjutnya adalah bagaimana membuat foto produk yang baik dan menarik belum banyak pelaku UMKM yang menguasainya sehingga yang terjadi adalah fotofoto produk yang ditampilkan hanya sekadarnya.

\section{KESIMPULAN}

Dari penelitian terhadap pelaku UMKM di Kota Surakarta mengenai dampak teknologi informasi, penggunaan teknologi informasi berdampak pada peningkatan jumlah pesanan yang diterima, peningkatan jumlah produksi, peningkatan pendapatan, dan penambahan konsumen yang baru. Sedangkan kendalakendala yang dihadapi dalam penggunaan teknologi informasi sebagian besar disebabkan oleh faktor internal dari pelaku UMKM yakni belum adanya pemisahan antara manajemen serta kemampuan penguasaan atas teknologi yang terbatas.

\section{SARAN}

Berdasarkan hasil penelitian di atas maka dapat disarankan kepada para pemangku kepentingan yang berkaitan dengan pengembangan UMKM khususnya pemerintah baik pusat maupun daerah yang membidangi UMKM, perguruan tinggi, BDS-P, LSM serta pihak swasta untuk dapat membantu para pelaku UMKM dengan memberikan berbagai kegiatan baik pendidikan maupun pelatihan yang berkaitan dengan teknologi informasi yang menunjang bagi pengembangan para pelaku UMKM.

Dengan adanya pemberdayaan ekonomi masyarakat khususnya pelaku UMKM maka diharapkan dapat meningkatkan kehidupan masyarakat yang lebih luas menuju kehidupan yang lebih baik dalam kebutuhan hidup, baik kebutuhan pokok serta kebutuhan dasarnya yang akhirnya akan berkontribusi bagi peningkatan perekonomian bangsa.

\section{DAFTAR PUSTAKA}

Afolayan, A., Plant, E., White, G.R., Jones, P. and Beynon-Davies, P., 2015. Information technology usage in SMEs in a developing economy. Strategic Change, 24(5), pp.483-498. DOI: $10.1002 /$ jsc. 2023

Ajayi, A. and Olayungbo, D., 2014. ICT adoption in small and medium scale enterprises in Nigeria: An assessment. International Journal of Research, 1(9), pp.889-897.

Apulu, I., Latham, A. and Moreton, R., 2011. Factors affecting the effective utilisation and adoption of sophisticated ICT solutions: Case studies of SMEs in Lagos, Nigeria. Journal of Systems and Information Technology.

As'ad, I., Ahmad, F. and Sentosa, I., 2012. An empirical study of e-commerce implementation among SME 
in Indonesia. International Journal of Independent Research and Studies, 1(1), pp.13-22.

Awa, H.O., Eze, S.C., Urieto, J.E. and Inyang, B.J., 2011. Upper echelon theory (UET): A major determinant of information technology (IT) adoption by SMEs in Nigeria. Journal of Systems and Information Technology. DOI $10.1108 / 13287261111135981$

Fahmi, I. 2016. Manajemen Produksi dan Operasi, Bandung: Alfabeta.

Ghobakhloo, M., Arias-Aranda, D. and Benitez-Amado, J. 2011. "Adoption of e-commerce applications in SMEs", Industrial Management \& Data Systems, Vol. $111 \quad$ No. 8, pp. 12381269. https://doi.org/10.1108/02635571111170785

Govindaraju, R. and Chandra, D.R., 2012. Analysis of level and barriers of e-commerce adoption by Indonesian small, medium, and micro enterprises (SMMEs). Internetworking Indones Journal, 4(1B), pp.9-14.

Karmawan, I.G.M., Sundjaja, A.M. and Luhukay, D., 2010, June. Analisis dan Perancangan E-commerce PD. Garuda Jaya. In Seminar Nasional Aplikasi Teknologi Informasi (SNATI).

Lubis, T.A., 2016. Pemanfaatan Teknologi Informasi pada Usaha Mikro Kecil dan Menengah di Kota Jambi. Jurnal Perspektif Pembiayaan dan Pembangunan Daerah, 3(3), pp.163-174.

Maryeni, Y.Y., Govindaraju, R., Prihartono, B. and Sudirman, I., 2014. E-commerce adoption by Indonesian SMEs. Australian Journal of Basic and Applied Sciences, 8(14), pp.45-49.

Mulyadi, R., 2014. Sistem Informasi Pendaftaran Mahasiswa Baru Program Beasiswa Unggulan Berbasis Web Pada Universitas Komputer Indonesia (Doctoral dissertation, Universitas Komputer Indonesia).

Niebel, T., 2018. ICT and economic growth-Comparing developing, emerging and developed countries. World Development, 104, pp.197-211. http://dx.doi.org/10.1016/j.worlddev.2017.11.024

Payu, B.R., 2013. Pemetaan UKM di Kota Gorontalo Berdasarkan Pola dan Tingkat Penggunaan Teknologi Informasi. Penelitian Unggulan Fakultas, 1(601).

Pickernell, D., Jones, P., Packham, G., Thomas, B., White, G. and Willis, R., 2013. E-commerce trading activity and the SME sector: an FSB perspective. Journal of Small Business and Enterprise Development. DOI 10.1108/JSBED-062012-0074

Rahayu, R. and Day, J., 2015. Determinant factors of ecommerce adoption by SMEs in developing country: evidence from Indonesia. Procedia-social and behavioral sciences, 195, pp.142-150. doi: 10.1016/j.sbspro.2015.06.423

Singh, R.K., 2011. Developing the framework for coordination in supply chain of SMEs. Business
Process Management Journal. DOI $10.1108 / 14637151111149456$

Sutabri, T., 2016. Sistem informasi manajemen.

Tarute, A. and Gatautis, R., 2014. ICT impact on SMEs performance. Procedia-social and behavioral Sciences, 110, pp.1218-1225.

Yunis, M., El-Kassar, A.N. and Tarhini, A., 2017. Impact of ICT-based innovations on organizational performance. Journal of Enterprise Information Management. http://dx.doi.org/10.1108/JEIM-012016-0040 